\title{
Orbital variations in planktonic foraminifera assemblages from the Ionian Sea during the Middle Pleistocene Transition
}

\author{
Alessandro Incarbona a,*, Jaume Dinarès-Turell b ${ }^{\mathrm{b}}$, Enrico Di Stefano ${ }^{\mathrm{a}}$, Giuseppe Ippolito a \\ Nicola Pelosi ${ }^{\mathrm{c}}$, Rodolfo Sprovieri ${ }^{\mathrm{a}}$ \\ a Università degli Studi di Palermo, Dipartimento di Scienze della Terra e del Mare, Via Archirafi 22, 90134 Palermo, Italy \\ b Istituto Nazionale di Geofisica e Vulcanologia, Via di Vigna Murata 605, 00143 Rome, Italy \\ c Consiglio Nazionale delle Ricerche, Istituto per l'Ambiente Marino Costiero, Calata Porto di Massa, Interno Porto di Napoli, 80133, Naples, Italy
}

\section{A R T I C L E I N F O}

\section{Article history:}

Received 21 May 2012

Received in revised form 25 October 2012

Accepted 26 October 2012

Available online 5 November 2012

\section{Keywords:}

Middle Pleistocene Transition

Planktonic foraminifera

Ionian Sea

Orbital climate variability

Neogloboquadrina pachyderma sinistral coiling

\begin{abstract}
A B S T R A C T
The Middle Pleistocene Transition (1.2-0.7 Ma) is the most recent re-organization of the global climate system which includes variations in the frequency and amplitude of glacial/interglacial cycles, increased ice sheet volume, sea surface temperature cooling and a significant drop in the $\mathrm{CO}_{2}$ atmospheric levels. Here we present high-resolution planktonic foraminifera data (mean sampling resolution of about 780 years) from core LC10 recovered in the Ionian Sea (eastern Mediterranean), between 1.2 and 0.9 Ma.

Selected taxa, among them G. ruber, T. quinqueloba and G. bulloides, show significant periodicities that can be associated to orbital cycles, mainly precession and obliquity. The planktonic foraminifera based paleoclimatic curve exhibits a cooling linear trend that can be associated to similar phenomena observed in the North Atlantic. On the other hand, we refer to the influence of the North African Monsoon the occurrence of two peaks of the low-salinity tolerant species $G$. quadrilobatus that fall in coincidence of sapropel layers. Finally, we discuss the distribution pattern of N. pachyderma sinistral coiling, with peaks up to about $20 \%$ between MIS 30 and 28, and compare it to middle-late Quaternary records of the Sicily Channel and western Mediterranean.
\end{abstract}

(c) 2012 Elsevier B.V. All rights reserved.

\section{Introduction}

The Middle Pleistocene Transition (MPT) that lasted from 1.2 to 0.7 million years ago, is the most recent re-organization of the global climate system. Glacial/interglacial cycles with 100-kiloyear (kyr) pacing replaced lower amplitude 41-kyr cycles without a modification in the Earth's orbital parameters (Pisias and Moore, 1981; Lisiecki and Raymo, 2005). Researchers have documented a series of phenomena associated to the MPT: an increase in ice sheet volume, sea surface temperature (SST) cooling in the oceans, variations in the Atlantic Meridional Overturning Circulation (AMOC), a significant drop in the $\mathrm{CO}_{2}$ atmospheric levels, stronger African and Asian monsoon activity and increased dust deposition in the Southern Ocean (e.g. Ruddimann et al., 1989; Mix et al., 1995; Venz and Hodell, 2002; Hodell et al., 2003; Schefus et al., 2004; Lisiecki and Raymo, 2005; McClymont and Rosell-Melè, 2005; Clark et al., 2006; Sun et al., 2006; Martínez-Garcia et al., 2011).

A high sensitivity of the Mediterranean Sea to orbital and suborbital climatic variations has been proven, even for late Quaternary abrupt changes (e.g. Lourens et al., 1996; Martrat et al., 2004; Sprovieri et al., 2006; Incarbona et al., 2008a). The Mediterranean basin climate is characterized by global scale connections. The descending branch of the

\footnotetext{
* Corresponding author.

E-mail address: alessandro.incarbona@unipa.it (A. Incarbona).
}

Hadley circulation affects the area in summer and is coupled to the zonal tropical circulation which is interconnected with the Indian and African Monsoon. Westerlies prevail during the winter season and their track and strength is mostly controlled by the North Atlantic Oscillation (Bolle, 2003).

The Mediterranean Sea is ideally located to reveal climatic system interplays during the MPT. However, only a few studies focused on this region, analysing the response of the vegetational patterns, calcareous nannofossils and oxygen isotopes (Maiorano and Marino, 2004; Maiorano et al., 2004; Joannin et al., 2008, 2011; Marino et al., 2008; Ciaranfi et al., 2010). Here we show high-resolution ( 780 years) data of planktonic foraminifera assemblages, in order to investigate the evolution of surface water characteristics, mainly in terms of SST and productivity. We examine the periodicity of abundance variations recognized in selected taxa, in comparison with orbital parameters. Finally, we try to assess the impact of different climate systems in the Ionian Sea surface water during the MPT.

\section{Materials and Methods}

Core $\mathrm{LC} 10\left(35^{\circ} 12.77^{\prime} \mathrm{N} ; 16^{\circ} 34.88^{\prime} \mathrm{E}\right)$ was recovered by the R/V Marion Dufresne in 1995, from a bank north of Heron Valley in the Ionian Sea, at a depth of $1322 \mathrm{~m}$ (Fig. 1). The core consists of about $20 \mathrm{~m}$ of greyish yellow olive grey foraminifer-rich mud and nannofossil ooze. A thin tephra layer is located at about $4.55 \mathrm{~m}$ below sea floor (mbsf), 


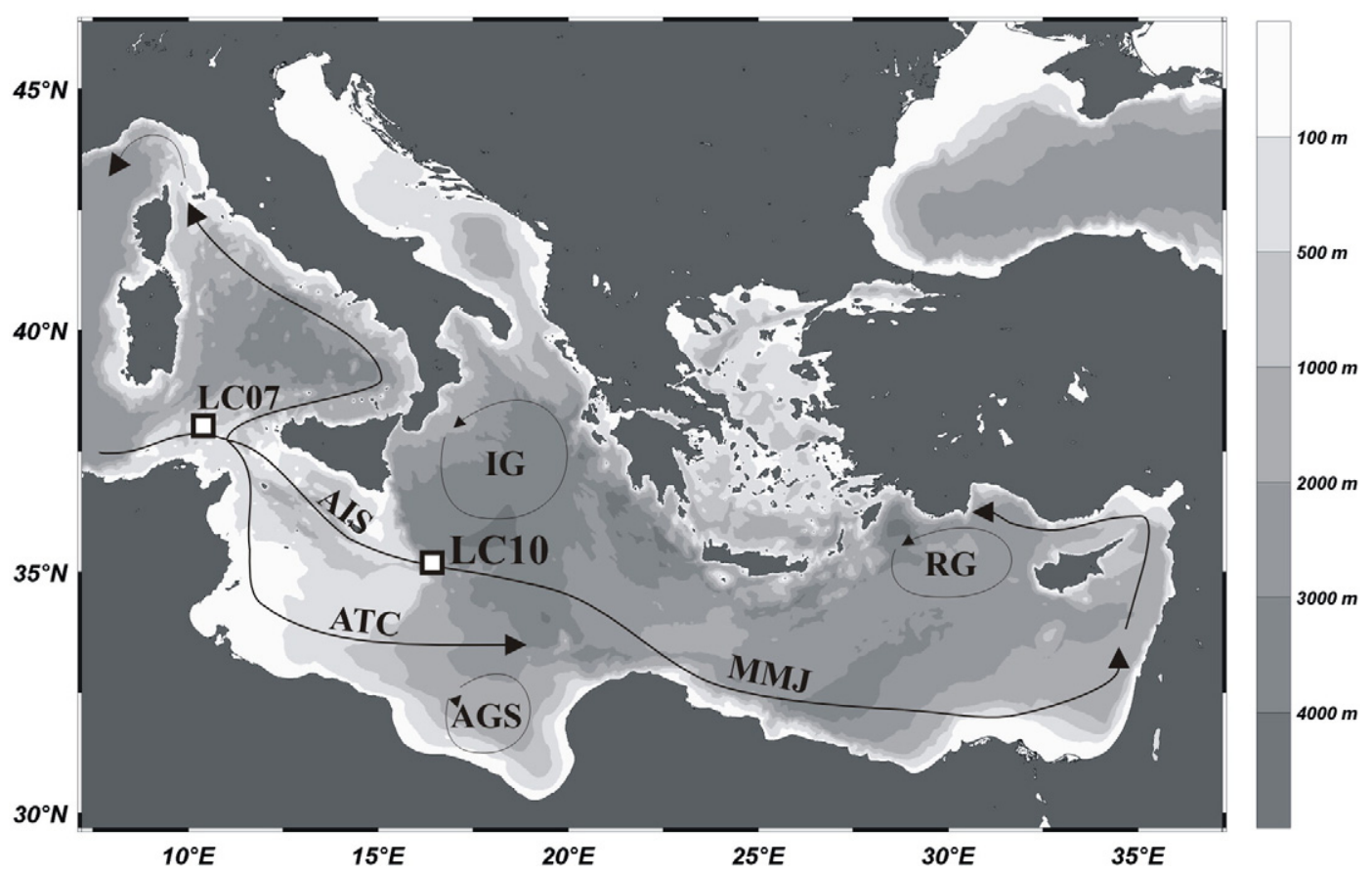

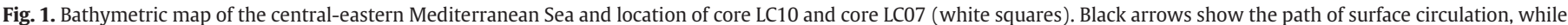

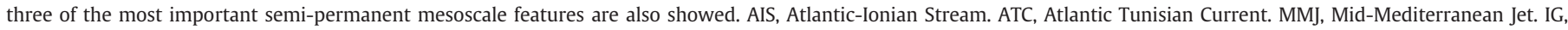

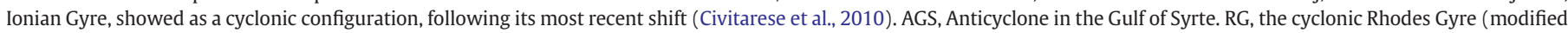
from Pinardi and Masetti, 2000).

while several dark sapropelitic layers have been recognized in the sedimentary sequence. Three of them are within the investigated interval, at about 16.50, 18.00 and 18.60 mbsf (Dinarès-Turell et al., 2003).

Planktonic foraminifera were studied every $1 \mathrm{~cm}$ in the interval between 19.82 and 15.87 mbsf. Samples were dried and washed on a $63 \mu \mathrm{m}$ sieve. The relative abundance of each species was obtained from splits of about 300 specimens, in the residue greater than $125 \mu \mathrm{m}$. Fifteen species or species groups were distinguished, following Bolli et al. (1985) and Hemleben et al. (1989) taxonomic concepts. Globigerinoides ruber includes Globigerinoides elongatus. Globigerinoides quadrilobatus includes Globigerinoides trilobus and Globigerinoides sacculifer. Globigerina bulloides includes Globigerina falconensis. The paleoclimatic curve presented here is the algebraic sum of warm-water species percentages (G. ruber, Hastigerina siphonifera, G. sacculifer, Globoturborotalita rubescens and Globoturborotalita tenella) expressed as positive values and cold-water species percentages (Neogloboquadrina pachyderma, G. bulloides, Turborotalita quinqueloba, Globorotalia scitula and Globigerinita glutinata) expressed as negative values (Corselli et al., 2002; Sprovieri et al., 2006; Incarbona et al., 2010). In fact, among others, G. ruber ecological preference for warm and oligotrophic surface waters has been established in numerous oceanographic settings (Hemleben et al., 1989; Pujol and Vergnaud-Grazzini, 1995; Žarić et al., 2005) and paleoceanographic reconstructions (Sprovieri et al., 2003, 2006, 2012); T. quinqueloba thrives in cold and nutrient-rich surface waters (Hemleben et al., 1989; Pujol and Vergnaud-Grazzini, 1995; Žarić et al., 2005); N. pachyderma dx lives in cold waters of middle-high latitude and is a proxy for deep chlorophyll maximum levels (e.g. Rohling and Gieskes, 1989).

Calcareous nannofossil analysis was carried out by observation with a polarized microscope at about $1000 \times$ magnification, sampling every $10 \mathrm{~cm}$ between 17.60 and 16.50 mbsf. Rippled smear slides were prepared following the standard procedure (Bown and Young, 1998). Two counting methodologies were applied to detect the re-entrance of medium-sized Gephyrocapsa event: the analysis of 5000 specimens of the whole assemblage and the analysis of 100 specimens within the genus Gephyrocapsa.
The 'REDFIT' power spectrum (Schulz and Mudelsee, 2002), a modified version of the Lomb-Scargle periodogram (Lomb, 1976; Scargle, 1982), was used to search possible periodicities recorded in the nonuniformly sampled signal of planktonic foraminifera species. A first-order autoregressive process (AR1) was carried out by REDFIT directly from unevenly spaced time series without requiring interpolation, to test if peaks of the signals are significant against the red-noise background.

Magnetic measurements were carried out every $1 \mathrm{~cm}$ with a 2-G Enterprises cryogenic magnetometer fitted with an inline coil to measure magnetic susceptibility. Since no additional analyses were carried out in the present paper, we refer to Dinarès-Turell et al. (2003) where magnetic measurements methodology for core LC10 is widely discussed.

\section{Study area}

Surface waters, called Modified Atlantic Water (MAW), enter the eastern Mediterranean Sea from the Sicily Channel (Fig. 1) and occupy the first 100-200 $\mathrm{m}$ of the water column. In particular, the northern branch of the Sicily Channel stream, called the Atlantic Ionian Stream (AIS), contributes to the MAW transport into the eastern Mediterranean off the southern coast of Sicily (Robinson et al., 1999; Béranger et al., 2004). AIS meanders into the Ionian Sea and feeds the mid-Mediterranean jet that flows in the central Levantine basin up to Cyprus (POEM group, 1992; Pinardi and Masetti, 2000).

Levantine Intermediate Water (LIW) forms in the eastern basin in February-March as a process of surface cooling on water masses which underwent a severe salt enrichment in the area between Rhodes and Cyprus (Ovchinnikov, 1984). LIW occupies a depth between 150-200 and $600 \mathrm{~m}$ and is prevalent and ubiquitous throughout the Mediterranean Sea, contributing to the dense water formation in the northern part of the basin (POEM group, 1992; Millot, 1999).

Dense water forms in the northern part of the eastern basin (Eastern Mediterranean Deep Water-EMDW), in the Adriatic and Aegean Sea and is preconditionated by the presence of permanent cyclonic 
gyres (Fig. 1). The detailed formation process is not well known and understood. It starts with the blowing of very cold and dry air masses (Bora and Etesian) which cause deep convection throughout the water column. Sunken surface water admixes with LIW and fills the sea bottom. In the case of the Adriatic Sea, the newly formed EMDW exits through the Strait of Otranto and plunges to the deep western boundary of the Ionian basin (POEM group, 1992).

The trophic resources of the Mediterranean Sea are among the poorest in the world's oceans and the anti-estuarine circulation pattern contributes to its maintenance (Bethoux, 1979; Sarmiento et al., 1988). Primary production is controlled by the seasonal dynamics of the water column, with biomass increase in late winter/early spring and very low values in summer (Morel and André, 1991; Antoine et al., 1995; Bosc et al., 2004; D'Ortenzio and Ribera d'Alcalà, 2009). There is a significant west-east trophic gradient, with a reduction in primary productivity in the eastern basin of over a factor of three (Bosc et al., 2004; D'Ortenzio and Ribera d'Alcalà, 2009), which follows the same increasing nutrient depletion trend, particularly exacerbated for phosphorous (Krom et al., 1991, 2010). Productivity estimates of the Ionian Sea suggest that it is the most oligotrophic subbasin together with the Levantine Sea (Antoine et al., 1995; D'Ortenzio et al., 2003; Bosc et al., 2004). Moreover, primary productivity reflects the hydrological fragmentation due to mesoscale variability. Core LC10 is only a few tens of kilometres from the Ionian Gyre (Fig. 1) which seems to switch from a cyclonic to an anticyclonic configuration at a decadal scale, affecting the biological productivity in the northern Ionian and southern Adriatic Sea (Civitarese et al., 2010; Gačić et al., 2010).

\section{Age model}

It has been shown that a climatic forcing mechanism controls the rock magnetic signature in cores LC07 (western Sicily Channel) and LC10 (Dinarès-Turell et al., 2003, 2002). The variations appear to be related to the magnetite grain size, with glacial periods dominated by the relatively coarse magnetite grains due to enhanced African dust input, alternating with fine-grained magnetite formed by magnetotactic bacteria during interglacials. In particular, in core LC07 (Fig. 1), the validity of the age model construction has been supported by the analysis of oxygen isotopes and calcareous planktonic assemblages (Incarbona et al., 2008b).

A slight modification to the LC10 age model, as originally proposed by Dinarès-Turell et al. (2003), has been carried out: the tuning of the magnetic susceptibility was performed on the more recent 'LR04' benthic stack (Lisiecki and Raymo, 2005). The negative peak of magnetic susceptibility interpreted as MIS 27 by Dinarès-Turell et al. (2003) was shifted down, to include the light values peak of MIS 28 in the 'LR04' benthic stack (Fig. 2). A linear interpolation has been carried out among the adopted tie-points, that is MISs transition midpoints, listed in Table 1.

A further control on the validity of the age model was provided by the calcareous nannofossil biostratigraphy. The re-entrance of mediumsized Gephyrocapsa, that marks the MNN19f zone (Rio et al., 1990), has been recognized at 16.90 mbsf, counting 5000 coccoliths, in the lower part of MIS 26 (Fig. 2). The same event has been found at $16.60 \mathrm{mbsf}$ with the analysis of 100 Gephyrocapsa spp. specimens, that is within MIS 25. In any case, this bioevent falls within the interval MIS 26/MIS 25 , in agreement with other reports from the eastern Mediterranean Sea (Raffi, 2002; Maiorano and Marino, 2004).

The sedimentation rates show a mean value of $1.29 \mathrm{~cm} / \mathrm{kyr}$ (Fig. 3) which is comparable to other Middle Pleistocene records in the Ionian Sea (e.g. Sprovieri et al., 1998; Lourens, 2004; Di Stefano and Incarbona, 2008). In spite of the very detailed sampling strategy (every $1 \mathrm{~cm}$ ), the resolution of planktonic foraminifera data spans from about 510 years to 1330 years (Table 1 ), with a mean value of 776.8 years.

\section{Results}

Planktonic foraminifera shells in core LC10 are well preserved and the assemblages are well diversified. About 20 taxa have been identified, but only G. ruber, T. quinqueloba, G. bulloides, G. inflata and Orbulina spp. show repeated abundance fluctuations that are associated with glacial/interglacial cycles (Fig. 4). G. quadrilobatus exhibits three distinctive peaks at the transition of MISs 35/34, MISs 31/30 and MISs 25/24 (Fig. 4). N. pachyderma dx is more abundant since the base of MIS 30, while N. pachyderma sx is mostly limited between MISs 30 and 28 (Fig. 4).

The planktonic foraminifera paleoclimatic curve shows repeated negative (cold surface water) and positive (warm surface water) fluctuations which are usually linked to respectively even and odd MISs. Sometimes, two or three warm water peaks have been recognized within the longest MISs, such as MIS 35 and 25 (Fig. 2), possibly following the division in substages. In addition, we argue that highfrequency switches today observed in the oceanographic mesoscale feature of the Ionian Sea (Civitarese et al., 2010) may have acted in the past, affecting the thermal character of surface water, for instance by upwelling phenomena during the cyclonic configuration.

The spectral analysis demonstrates the occurrence of periodicities, over the 95\% confidence level, in all selected taxa. Cycles close to 19-23 kyr and to $40 \mathrm{kyr}$ have been found for instance in the planktonic foraminifera paleoclimatic curve, G. bulloides, Orbulina spp., T. quinqueloba and G. ruber (Fig. 5). In addition, the planktonic foraminifera assemblages display other significant periodicities at about $30 \mathrm{kyr}, 50 \mathrm{kyr}, 60 \mathrm{kyr}$ and $80 \mathrm{kyr}$ (Fig. 5).

\section{Discussion}

6.1. The influence of the North Atlantic climate system and of the African Monsoon

The magnetic susceptibility record at site LC10 is interpreted as a proxy for Saharan dust deposition and, indirectly, to the monsoon activity strength (Dinarès-Turell et al., 2003). The highest values, associated with even MISs, may be the result of increased dust deposition due to the aridity in North African regions which led to a reduced vegetation and an increased erosion (deMenocal, 1995, 2004; Dinarès-Turell et al., 2003). The spectral analysis shows a major periodicity centred at about $40 \mathrm{kyr}$ and a weaker one at about $20 \mathrm{kyr}$, respectively tied to the obliquity and precession cycles (Fig. 5), like other records in the eastern Mediterranean and the western African margin during the MPT (deMenocal, 1995; Larrasoaña et al., 2003; deMenocal, 2004; Trauth et al., 2009).

The LR0 4 benthic stack curve shows the same linear trend towards heavier oxygen isotopic values (Fig. 2) and the same periodicities linked to obliquity and precession (Fig. 5) have been observed in the North Atlantic Ocean (e.g. Ruddimann et al., 1989; Raymo et al., 1990; Tiedemann et al., 1994; Kleiven et al., 2003; Clark et al., 2006).

Most of the selected planktonic foraminifera taxa at site LC10 show significant periodicities linked to the obliquity and to the precession (Fig. 5). Also the cycles of about $30 \mathrm{kyr}, 50 \mathrm{kyr}, 60 \mathrm{kyr}$ and $80 \mathrm{kyr}$ commonly found in other paleoclimatic records, can be ascribed to the interaction among, or to a multiple of, primary orbital periods (e.g. Negi and Tiwari, 1984; Rea, 1994; Huybers and Wunsch, 2005; Tziperman et al., 2006; Marino et al., 2009). Thus it is very hard to distinguish between the African Monsoon and the North Atlantic climate system influence in the eastern Mediterranean record on the basis of the spectral analysis. However, we argue that a clue of the contribution of these two climate systems can be deduced by considerations on the Sea Surface Temperature (SST) and the ecological preference and biogeographical distribution of some taxa, specifically N. pachyderma sx (see Section 6.2 below) and G. quadrilobatus. 

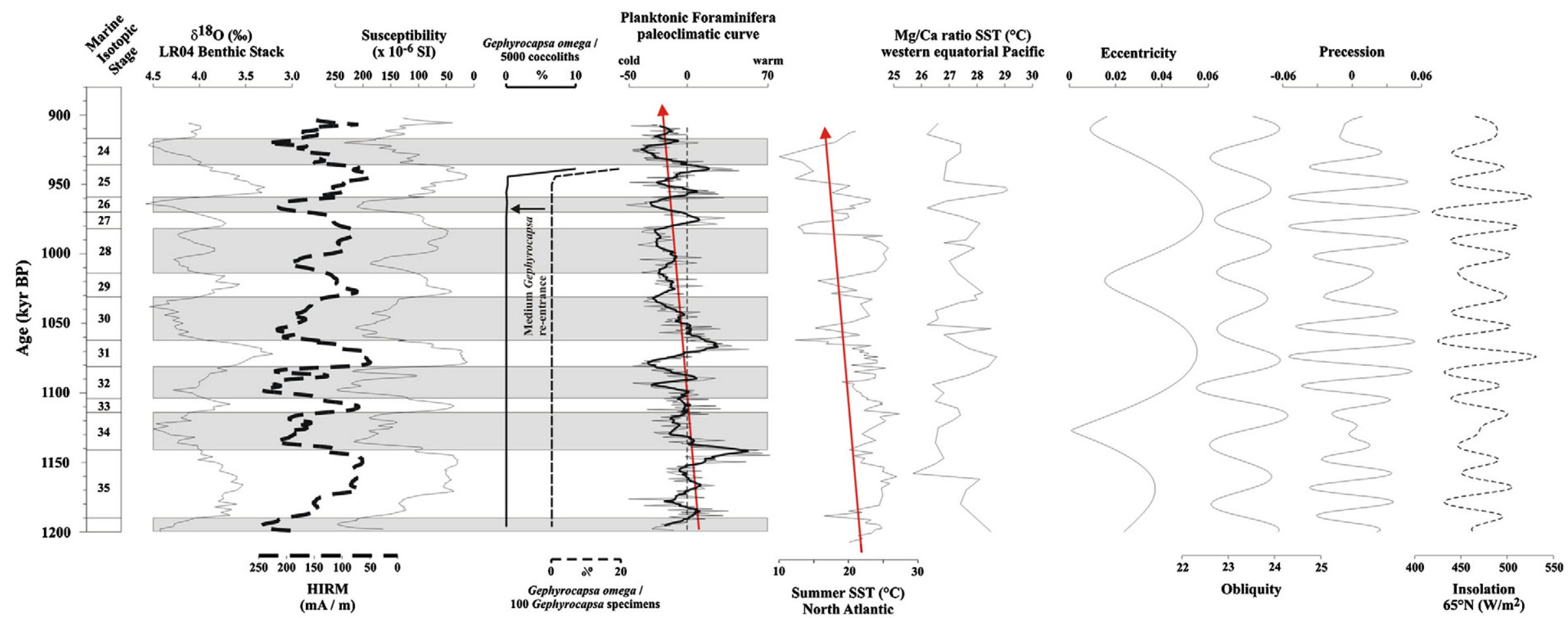

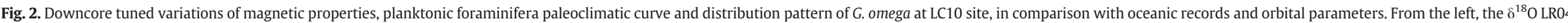

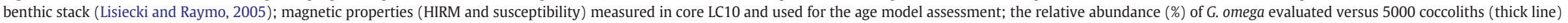

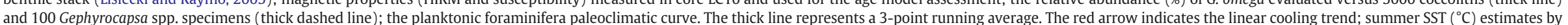

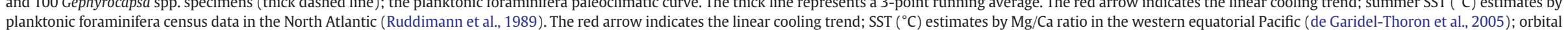
parameters and summer insolation at $65^{\circ} \mathrm{N}$ (Laskar et al., 2004). Light grey and white bands represent the alternation of respectively even (glacial) and odd (interglacial) MISs. 
Table 1

Data used for the age model construction. From the left, marine isotopic stage boundaries. Note that the asterisk in the $28 / 27$ boundary indicates that it was shifted down to include the light values peak of MIS 28 (see Chapter 4 and Fig. 2); ages (kyr) imported from the $\delta^{18} \mathrm{O}$ LR04 benthic stack (Lisiecki and Raymo, 2005); depth (mbsf) of MISs at core LC10, recognized on the basis of magnetic susceptibility data (Dinarès-Turell et al., $2003)$; sedimentation rates $(\mathrm{cm} / \mathrm{kyr}$ ) calculated on the basis of linear interpolation between the adopted tie-points and the subsequent sampling resolution (years).

\begin{tabular}{|c|c|c|c|c|}
\hline $\begin{array}{l}\text { MIS } \\
\text { boundary }\end{array}$ & $\begin{array}{l}\text { Age } \\
(\mathrm{kyr})\end{array}$ & $\begin{array}{l}\text { Depth } \\
\text { (mbsf) }\end{array}$ & $\begin{array}{l}\text { Sedimentation rate } \\
(\mathrm{cm} / \mathrm{kyr})\end{array}$ & $\begin{array}{l}\text { Sampling resolution } \\
(1 \mathrm{~cm})\end{array}$ \\
\hline $24 / 23$ & 917 & 16.08 & & \\
\hline 24 & & & 1.95 & 513.5 \\
\hline $25 / 24$ & 936 & 16.45 & & \\
\hline 25 & & & 1.78 & 561.0 \\
\hline $26 / 25$ & 959 & 16.86 & & \\
\hline 26 & & & 1.00 & 1000.0 \\
\hline $27 / 26$ & 970 & 16.97 & & \\
\hline 27 & & & 0.88 & 1142.9 \\
\hline $28 / 27^{*}$ & 1002 & 17.25 & & \\
\hline 28 & & & 0.75 & 1333.3 \\
\hline $29 / 28$ & 1014 & 17.34 & & \\
\hline 29 & & & 1.06 & 944.4 \\
\hline $30 / 29$ & 1031 & 17.52 & & \\
\hline 30 & & & 1.16 & 861.1 \\
\hline $31 / 30$ & 1062 & 17.88 & & \\
\hline 31 & & & 1.68 & 593.7 \\
\hline $32 / 31$ & 1081 & 18.20 & & \\
\hline 32 & & & 1.52 & 657.1 \\
\hline $33 / 32$ & 1104 & 18.55 & & \\
\hline 33 & & & 1.50 & 666.7 \\
\hline $34 / 33$ & 1114 & 18.70 & & \\
\hline 34 & & & 1.52 & 658.5 \\
\hline $35 / 34$ & 1141 & 19.11 & & \\
\hline 35 & & & 1.24 & 803.3 \\
\hline $36 / 35$ & 1190 & 19.72 & & \\
\hline
\end{tabular}

The latter species lives in warm surface waters characterized by relatively lower salinity (Bé and Tolderlund, 1971; Hemleben et al., 1989; Pujol and Vergnaud-Grazzini, 1995; Sprovieri et al., 2003). In

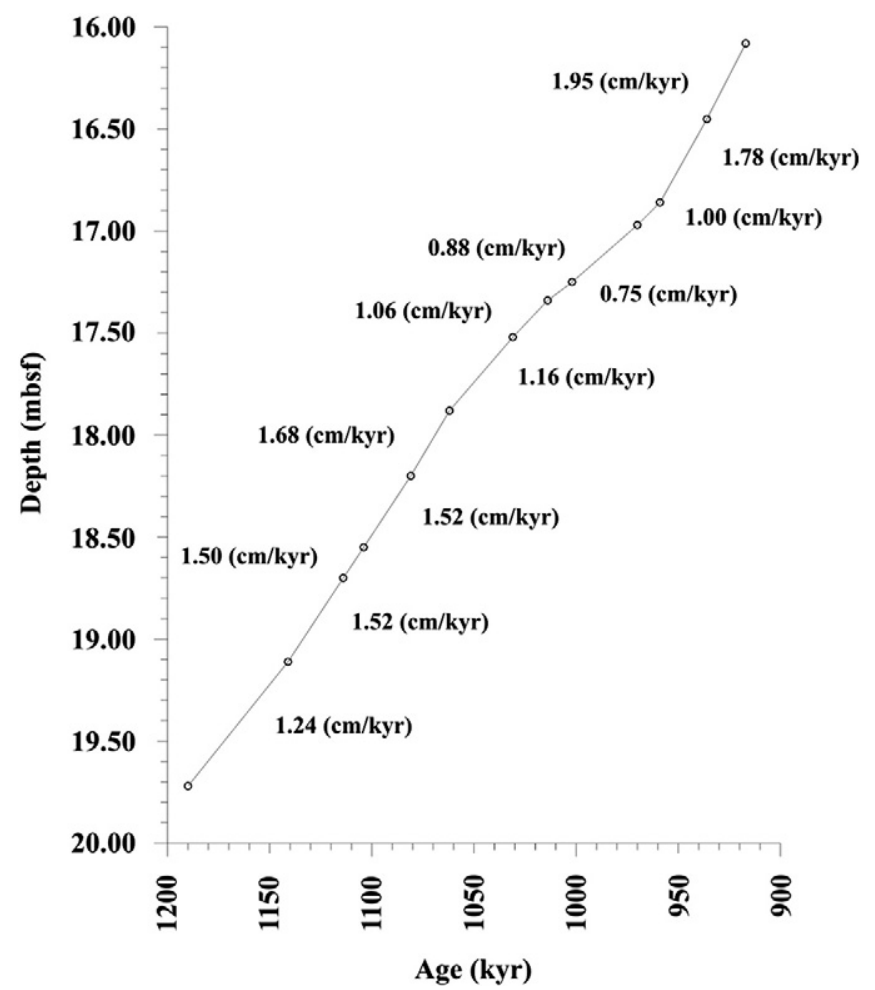

Fig. 3. Age (kyr) versus depth (mbsf) plot of core LC10. Open circles indicate the adopted tie-points, while sedimentation rate values of the different segments are also indicated. the LC10 record, two distinctive peaks of G. quadrilobatus coincide with two sapropel layers, at about $1070 \mathrm{kyr}$ and $940 \mathrm{kyr}$ (Fig. 4). Several hypotheses have been formulated for the development of bottom anoxia in the Eastern Mediterranean Sea, mainly linked to higher productivity levels and the weakening/interruption of deep water formation (Rohling, 1994; Cramp and O'Sullivan, 1999). In any case, the exceptional African Monsoon activity, and the consequent strong Nile (and other presently buried North African) river runoff, was a prime forcing factor of this phenomenon (Rossignol-Strick, 1983, 1985; Hilgen, 1991; Lourens et al., 1996; Rohling et al., 2002a, 2004; Marino et al., 2007, 2009). Thus, the two peaks of G. quadrilobatus may be an indirect response to the tropical climate influence. However, the oldest, and most pronounced, peak of G. quadrilobatus occurs at about $1145 \mathrm{kyr}$. The grey reflectance analysis did not record any significant darkening in coincidence of this interval (Dinarès-Turell et al., 2003), but the timing of this horizon is suspect, given that at Ocean Drilling Program (ODP) Site 967 a red interval was noticed (Emeis et al., 2000). Trace element analysis, and especially the $\mathrm{Ba} / \mathrm{Al}$ profile, would be needed to clarify the original nature of sediments deposited at LC10 site $1145 \mathrm{ka}$. Finally, we note that there is no any significant abundance increase of this species at about $1110 \mathrm{kyr}$, when the third sapropel was deposited (Fig. 4). This behaviour may be due to the increased importance of factors, other than Nile river runoff, for the formation of this sapropel layer, such as primary productivity (e.g. Calvert et al., 1992). Alternatively, ecological factors like SST and food availability may have limited the G. quadrilobatus' population, regardless of sea surface salinity.

The planktonic foraminifera paleoclimatic curve indicates an obvious pattern of warm oligotrophic water during odd MISs and cold and more productive water during even ones. The power spectrum of this curve shows significant periodicities tied to precession, obliquity and surprisingly also to eccentricity (about $100 \mathrm{kyr}$ ) that is not captured by the magnetic susceptibility record at site LC10 and by the LR0 4 benthic stack curve (Fig. 5). However, we point out that the linear trend of cooling in the Ionian Sea surface waters during the MPT seems to parallel Atlantic Ocean records, whilst contrasting evidence on the SST trends exists in the Pacific Ocean (Fig. 2) (Ruddimann et al., 1989; Marlow et al., 2000; Schefus et al., 2004; de Garidel-Thoron et al., 2005; McClymont and Rosell-Melè, 2005; Clark et al., 2006). Teleconnection phenomena between the Mediterranean and the Greenland/North Atlantic region are documented for the late Quaternary (e.g. Rohling et al., 1998; Cacho et al., 1999; Sbaffi et al., 2001; Rohling et al., 2002b; Sprovieri et al., 2003; Martrat et al., 2004; Pérez-Folgado et al., 2004; Sprovieri et al., 2006; Incarbona et al., 2008a). This connection has been explained by variations in North Atlantic Deep Water formation rate, as modelling experiments suggest that this mechanism is able to cause coherent temperature changes in the two regions (e.g. Manabe and Stouffer, 1997; Vellinga and Wood, 2002). Thus, we refer the cooling trend observed in our record to the influence of the northern climate system and specifically to the Atlantic Meridional Overturning Circulation and North Atlantic SST.

\subsection{The distribution of $N$. pachyderma $s x$}

The first appearance of the modern-type of $N$. pachyderma sx specimens, that can be used as a paleotemperature proxy, occurred about 1250 kyr ago in the oceans (Kucera and Kennett, 2002). Thus, the significant pulsation of this species in the Ionian Sea record between MIS 30 and 28 (Fig. 4) is a real evidence of severe cold surface water. It is striking the relative abundance magnitude, up to about 20\% (Fig. 4), in comparison with its rarity $(<5 \%)$ in the central/eastern Mediterranean during the late Quaternary (e.g. Thunell, 1978; Rohling and Gieskes, 1989; Rohling et al., 1993; Hayes et al., 1999; Sprovieri et al., 2003; Hayes et al., 2005; Triantaphyllou et al., 2009; Siani et al., 2010; Sprovieri et al., 2012). This situation is well illustrated by the long-range study of ODP Site 964, drilled in the Ionian Sea 


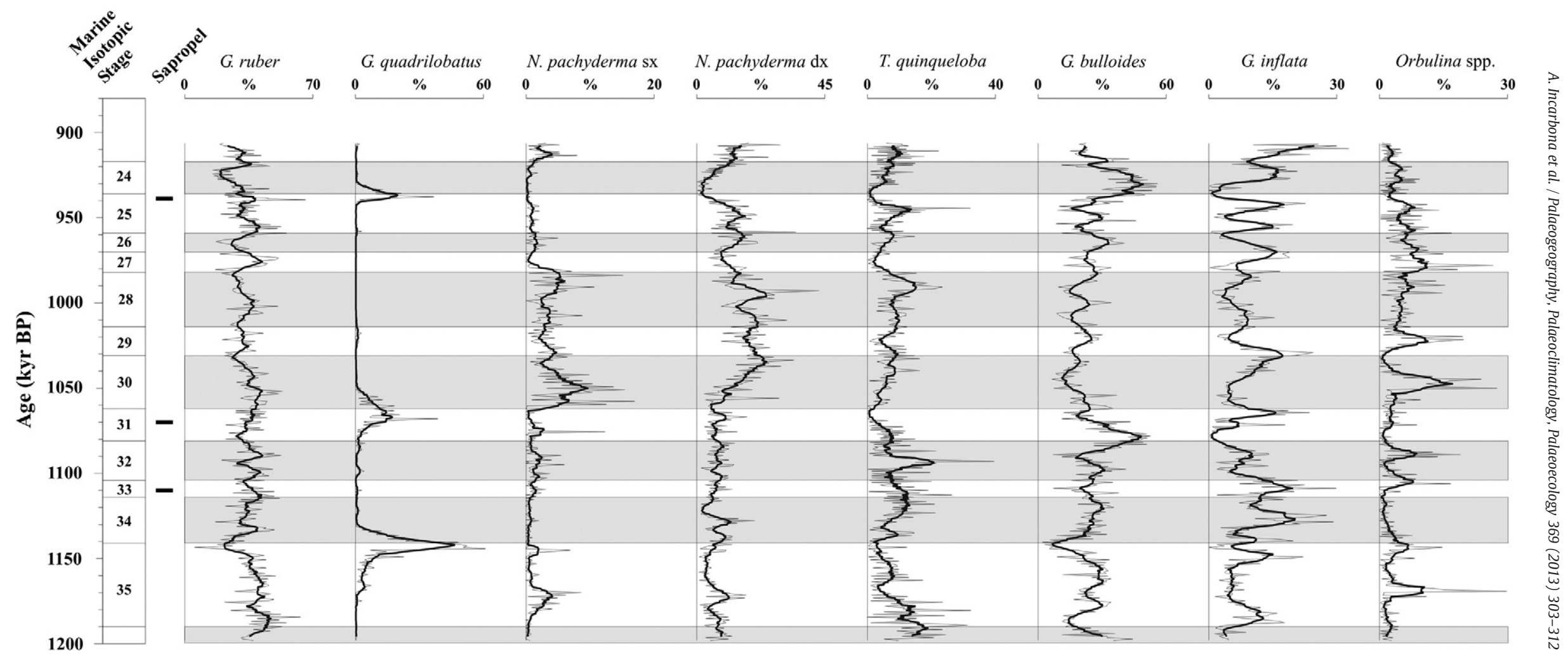

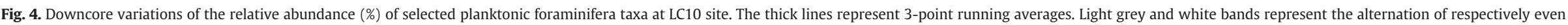
(glacial) and odd (interglacial) MISs. The three sapropel layers recognized in the studied interval by grey reflectance analysis (Dinarès-Turell et al., 2003) are showed as thick black segments. 


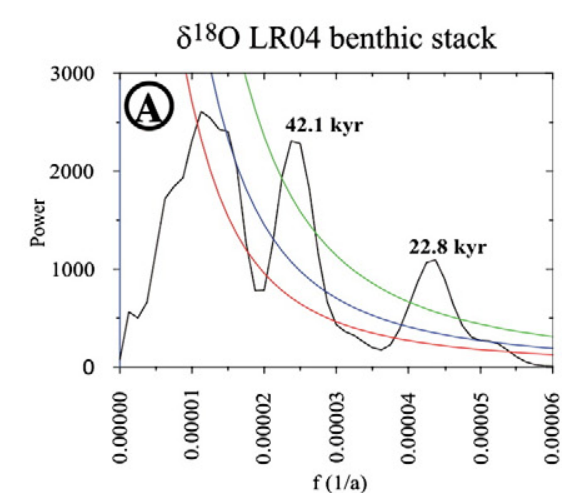

G. bulloides

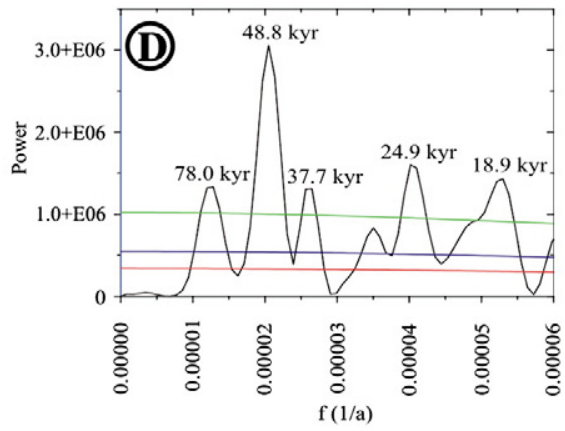

G. ruber

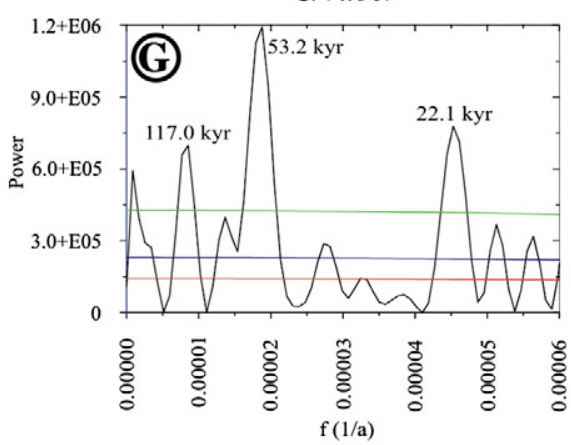

Orbulina spp.

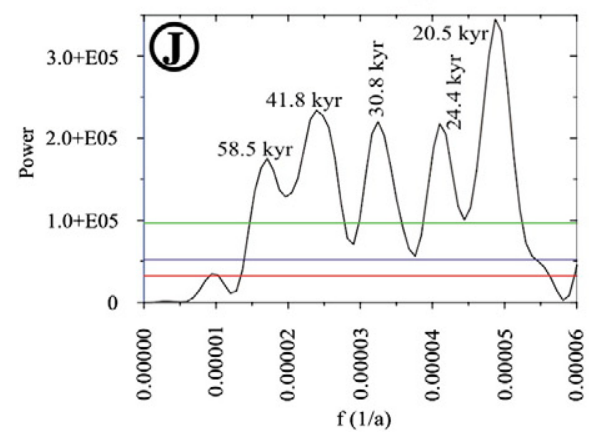

Magnetic susceptibility

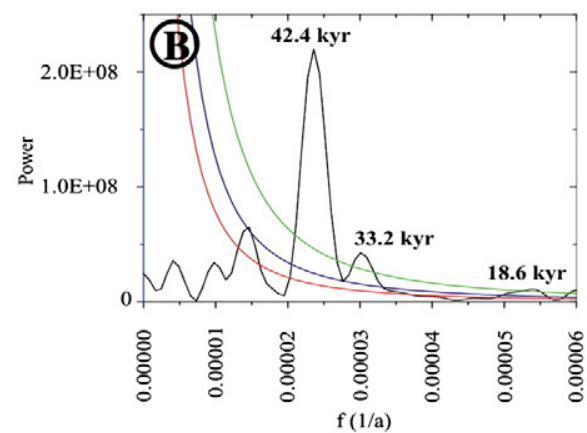

G. inflata

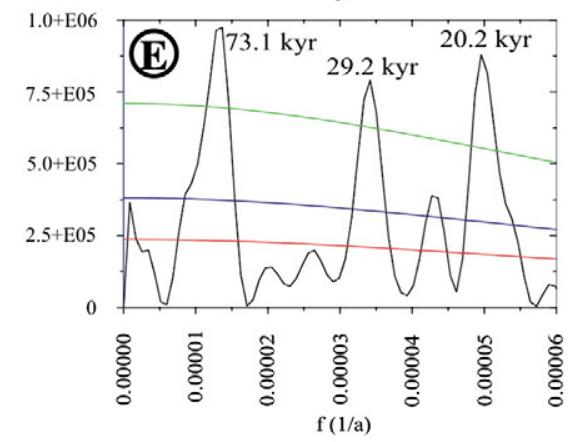

N. pachyderma $\mathrm{dx}$

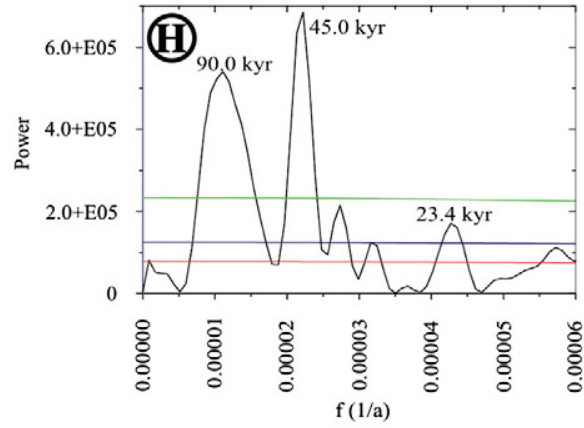

T. quinqueloba

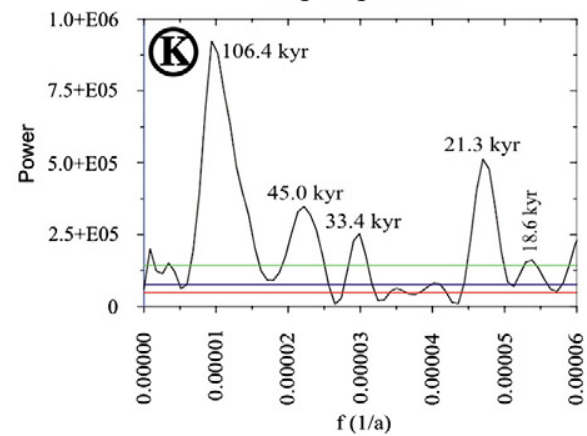

Planktonic foraminifera paleoclimatic curve

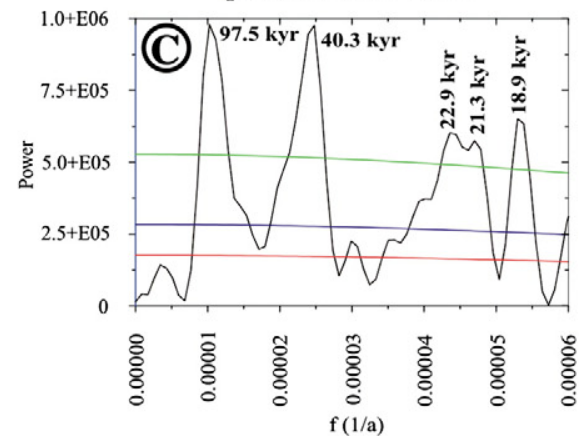

G. quadrilobatus

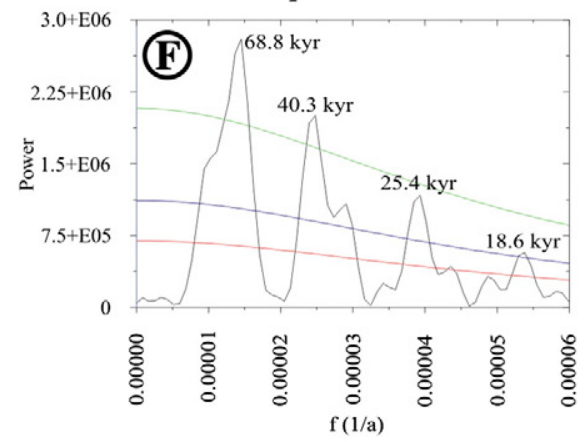

N. pachyderma $s \mathrm{x}$

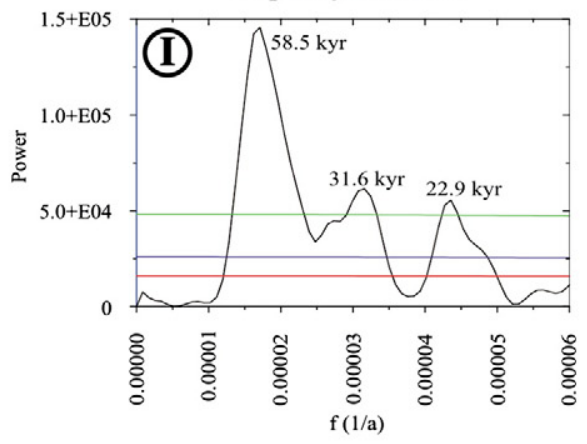

95\% confidence level

$90 \%$ confidence level

$85 \%$ confidence level

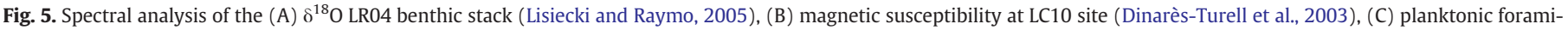
nifera paleoclimatic curve and (D-F) selected planktonic foraminifera taxa. Green, black and red curves indicate confidence levels at respectively 95,90 and $85 \%$.

(Sprovieri et al., 1998). Peaks of about 25\% of N. pachyderma sx occur within the nannofossil Zones MNN19e and MNN19f, that is around the MPT, while there is a general decrease and rarity above at that site. Interestingly, $N$. pachyderma sx shows the same long-range distribution pattern in the western Mediterranean. Peaks in abundance up to $80-90 \%$ are recorded at ODP sites 976 (Alboran Sea) and 975 (Balearic Rise), again between MNN 19e and MNN 19f Zones (Linares et al., 1999). Thereafter, in the western Mediterranean Sea several fluctuations with maxima values of $20 \%$ have been documented in coincidence of Heinrich events, during the last glacial periods 
(Rohling et al., 1998; Cacho et al., 1999; Pérez-Folgado et al., 2003; Sierro et al., 2005), and interpreted as the entrance of this species into the Mediterranean Sea during the southward shift of the Polar Front in the North Atlantic during the slow-down of North Atlantic Deep Water (NADW) formation.

We argue that the lower abundance of $N$. pachyderma sx in both the eastern and the western Mediterranean Sea after the MPT is paradoxical, since colder conditions and a much thicker ice accumulation in Greenland and Antarctica sheets are documented (Lisiecki and Raymo, 2005). Even the oceanographic process that leads to the entrance of $N$. pachyderma sx into the Gibraltar Strait during the cold spells of the Late Quaternary is not suitable as an analogue for the MPT, since the whole North Atlantic shows high $\delta^{13} \mathrm{C}$ values, with very low glacial/ interglacial variability that testifies to intense and persistent NADW formation (Raymo et al., 1990; Venz and Hodell, 2002; Kleiven et al., 2003; Clark et al., 2006). Further high-resolution studies would be needed to clarify the climatic/oceanographic forcing that controls the distribution and the dispersal of $N$. pachyderma sx in the Mediterranean basin during the middle-late Quaternary.

\section{Conclusion}

High-resolution planktonic foraminifera data, collected every $\sim 780$ years, from core LC10 recovered in the Ionian Sea allowed us to speculate on the surface marine ecosystem evolution during the MPT, between 1.2 and 0.9 Ma. Selected taxa, such as G. ruber, G. bulloides, G. inflata and T. quinqueloba, show significant periodicities that can be ascribed to orbital climate forcing. Cycles close to 19-23 kyr and to $40 \mathrm{kyr}$ can be respectively ascribed to precession and obliquity, whereas other significant periodicities at about 30, 50, 60 and $80 \mathrm{kyr}$ are best explained as the result of the interaction among primary orbital periods. Since obliquity and precession are the main periodicities also found in the North Atlantic oxygen isotopes (Ruddimann et al., 1989; Raymo et al., 1990; Tiedemann et al., 1994; Kleiven et al., 2003; Clark et al., 2006) and in the proxy curves of the African Monsoon intensity (deMenocal, 1995, 2004; Trauth et al., 2009), the spectral analysis of planktonic foraminifera assemblages at LC10 site is not able to determine the contribution of these two climate forcings.

The planktonic foraminifera paleoclimatic curve shows a cooling linear trend that can be correlated to a similar trend in the SST records of the North Atlantic (Ruddimann et al., 1989; Marlow et al., 2000; Schefus et al., 2004; Clark et al., 2006) and can be interpreted on the basis of teleconnection between the two regions. Two distinctive peaks of G. quadrilobatus, in coincidence of sapropel layers, may be the response to North African river runoff in the eastern Mediterranean and to the exceptional monsoon activity. Thus, at least in these two cases, we suggest that planktonic foraminifera assemblages may discriminate the main contribution of the North Atlantic climate system and the African monsoon on the eastern Mediterranean Sea marine environment.

Finally, we found a significant high relative abundance (up to 20\%) of the polar species N. pachyderma sx between MIS 30 and 28, that is striking in light of its very rare occurrence in the late Quaternary records of the central and eastern Mediterranean Sea (Thunell, 1978; Rohling and Gieskes, 1989; Rohling et al., 1993; Hayes et al., 1999; Sprovieri et al., 2003; Hayes et al., 2005). We argue that more data would be needed to understand the meaning of the distribution pattern of N. pachyderma sx and its dispersal into the Mediterranean Sea since the MPT.

\section{Acknowledgments}

We are grateful to two anonymous reviewers for comments and suggestions. This work was financially supported by MIUR ex $60 \%$ grants to E. Di Stefano.

\section{References}

Antoine, D., Morel, A., André, J.M., 1995. Algal pigment and primary production in the eastern Mediterranean as derived from CZCS observations. Journal of Geophysical Research 100, 16193-16210.

Bé, A.W.H., Tolderlund, D.S., 1971. Distribution and ecology of living planktonic foraminifera in surface waters of the Atlantic and Indian Oceans. In: Funnel, B.M., Riedel, W.R. (Eds.), The Micropaleontology of Oceans. Cambridge University Press, Cambridge, pp. 105-149.

Béranger, K., Mortier, L., Gasparini, G.-P., Gervasio, L., Astraldi, L., Crépon, M., 2004. The dynamics of the Sicily Strait: a comprehensive study from observations and models. Deep-Sea Research II 51, 411-440.

Bethoux, J.P., 1979. Budgets of the Mediterranean Sea. Their dependance on the local climate and on the characteristics of the Atlantic waters. Oceanologica Acta 2, 157-163.

Bolle, H.-J., 2003. Mediterranean Climate - Variability and Trends. Springer, Berlin, pp. 1-372.

Bolli, H.M., Saunders, J.B., Perch-Nielsen, K., 1985. Plankton Stratigraphy. Cambridge University Press, Cambridge, United Kingdom, pp. 1-554.

Bosc, E., Bricaud, A., Antoine, D., 2004. Seasonal and interannual variability in algal biomass and primary production in the Mediterranean Sea, as derived from 4 years of seaWiFS observations. Journal of Geophysical Research. http://dx.doi.org/10.1029/ 2003GB002034.

Bown, P.R., Young, J.R., 1998. Techniques. In: Bown, P.R. (Ed.), Calcareous Nannofossil Biostratigraphy. Kluwer Academic Publishers, Dordrecht, Boston, London, pp. 16-32.

Cacho, I., Grimalt, J.O., Pelejero, C., Canals, M., Sierro, F.J., Flores, J.A., Shackleton, N., 1999 Dansgaard-Oeschger and Heinrich event imprints in Alboran Sea paleotemperatures. Paleoceanography 14, 698-705.

Calvert, S.E., Nielsen, B., Fontugne, M.R., 1992. Evidence from nitrogen isotope ratios for enhanced productivity during formation of eastern Mediterranean sapropels. Nature 359, 223-225.

Ciaranfi, N., Lirer, F., Lirer, L., Lourens, L.J., Maiorano, P., Marino, M., Petrosino, P., Sprovieri, M., Stefanelli, S., Brilli, M., Girone, A., Joannin, S., Pelosi, N., Vallefuoco, M., 2010. Integrated stratigraphy and astronomical tuning of Lower-Middle Pleistocene Montalbano Jonico land section (Southern Italy). Quaternary International 219, 109-120.

Civitarese, G., Gačić, M., Lipizer, M., Eusebi Borzelli, G.L., 2010. On the impact of the Bimodal Oscillating System (BiOS) on the biogeochemistry and biology of the Adriatic and Ionian Seas (Eastern Mediterranean). Biogeosciences 7, 3987-3997.

Clark, P.U., Archer, D., Pollard, D., Blum, J.D., Rial, J.A., Brovkin, V., Mix, A.C., Pisias, N.G., Roy, M., 2006. The middle Pleistocene transition: characteristics, mechanisms and implications for long-term changes in atmospheric $\mathrm{pCO}_{2}$. Quaternary Science Reviews 25, 3150-3184.

Corselli, C., Principato, M.S., Maffioli, P., Crudeli, D., 2002. Changes in planktonic assemblages during sapropel S5 deposition: Evidence from Urania basin Area, eastern Mediterranean. Paleoceanography 17. http://dx.doi.org/10.1029/PA000536.

Cramp, A., O'Sullivan, G., 1999. Neogene sapropels in the Mediterranean: A review. Marine Geology 153, 11-28.

D'Ortenzio, F., Ribera d'Alcalà, M., 2009. On the trophic regimes of the Mediterranean Sea: a satellite analysis. Biogeosciences 6, 139-148.

de Garidel-Thoron, T., Rosenthal, Y., Bassinot, F., Beaufort, L., 2005. Stable sea surface temperatures in western Pacific warm pool over the past 1.75 million years. Nature 433, 294-298.

deMenocal, P.B., 1995. Plio-Pleistocene African climate. Science 270, 53-59.

deMenocal, P.B., 2004. African climate change and faunal evolution during the Pliocene-Pleistocene. Earth and Planetary Science Letters 220, 3-24.

Di Stefano, E., Incarbona, A., 2008. Calcareous nannofossil biostratigraphy and chronostratigraphy of ODP Hole 964D (Eastern Mediterranean Sea). Rivista Italiana di Paleontologia e Stratigrafia 114, 313-322.

Dinarès-Turell, J., Sagnotti, L., Roberts, A.P., 2002. Relative geomagnetic paleointensity from the Jaramillo subchron to the Matuyama/Bruhnes boundary as recorded in a Mediterranean piston core. Earth and Planetary Science Letters 194, 327-341.

Dinarès-Turell, J., Hoogakker, B.A.A., Roberts, A.P., Rohling, E.J., Sagnotti, L., 2003. Quaternary climatic control of biogenic magnetite production and eolian dust input in cores from the Mediterranean Sea. Palaeogeography, Palaeoclimatology, Palaeoecology 190, 195-209.

D'Ortenzio, F., Ragni, M., Marullo, S., Ribera d'Alcalà, M., 2003. Did biological activity in the Ionian Sea change after the Eastern Mediterranean Transient? Results from the analysis of remote sensing observations. Journal of Geophysical Research C: Oceans and Atmospheres 108, 14-20.

Emeis, K.-C., Sakamoto, T., Wehausen, R., Brumsack, H.-J., 2000. The sapropel record of the eastern Mediterranean Sea - Results of Ocean Drilling Program Leg 160. Palaeogeography, Palaeoclimatology, Palaeoecology 158, 371-395.

Gačić, M., Eusebi Borzelli, G.L., Civitarese, G., Cardin, V., Yari, S., 2010. Can internal processes sustain reversals of the ocean upper circulation? The Ionian Sea example. Geophysical Research Letters 37. http://dx.doi.org/10.1029/2010GL043216.

Hayes, A., Rohling, E.J., De Rijk, S., Kroon, D., Zachariasse, W.J., 1999. Mediterranean planktonic foraminiferal faunas during the last glacial cycle. Marine Geology 153, 239-252.

Hayes, A., Kucera, M., Kallel, N., Sbaffi, L., Rohling, E.J., 2005. Glacial Mediterranean sea surface temperatures based on planktonic foraminifera assemblages. Quaternary Science Reviews 24, 999-1016.

Hemleben, C., Spindler, M., Anderson, O.R., 1989. Modern Planktonic Foraminifera. Springer Verlag, New York, pp. 1-363.

Hilgen, F.J., 1991. Astronomical calibration of Gauss to Matuyama sapropels in the Mediterranean and implication for the geomagnetic polarity time scale. Earth and Planetary Science Letters 104, 226-244. 
Hodell, D.A., Venz, K.A., Charles, C.D., Ninneman, U.S., 2003. Pleistocene vertical carbon isotope and carbonate gradients in the South Atlantic sector of the Southern Ocean. Geochemistry, Geophysics, Geosystems 4. http://dx.doi.org/10.1029/2002GC000367.

Huybers, P., Wunsch, C., 2005. Obliquity pacing of the Late-Pleistocene glacial cycles. Nature 434, 491-494.

Incarbona, A., Di Stefano, E., Patti, B., Pelosi, N., Bonomo, S., Mazzola, S., Sprovieri, R., Tranchida, G., Zgozi, S., Bonanno, A., 2008a. Holocene millennial-scale productivity variations in the Sicily Channel (Mediterranean Sea). Paleoceanography 23 (PA3204). http://dx.doi.org/10.1029/2007PA001581.

Incarbona, A., Di Stefano, E., Sprovieri, R., Bonomo, S., Censi, P., Dinarès-Turell, J., Spoto S., 2008b. Vertical structure variability of the water column and paleoproductivity reconstruction in the central-western Mediterranean during the late Pleistocene. Marine Micropaleontology 69, 26-41.

Incarbona, A., Di Stefano, E., Sprovieri, R., Bonomo, S., Pelosi, N., Sprovieri, M., 2010. Millennial-scale paleoenvironmental changes in the central Mediterranean durin the last interglacial: Comparison with European and North Atlantic records. Geobios 43, 111-122.

Joannin, S., Ciaranfi, N., Stefanelli, S., 2008. Vegetation changes during the late Early Pleistocene at Montalbano Jonico (Province of Matera, southern Italy) based on pollen analysis. Palaeogeography, Palaeoclimatology, Palaeoecology 270, 92-101.

Joannin, S., Bassinot, F., Comborieu Nebout, C., Peyron, O., Beaudouin, C., 2011. Vegetation response to obliquity and precession forcing during the Mid-Pleistocene Transition in Western Mediterranean region (ODP Site 976). Quaternary Science Reviews 30, 280-297.

Kleiven, H.F., Jansen, E., Curry, W.B., Hodell, D.A., Venz, K., 2003. Atlantic Ocean thermohaline circulation changes on orbital to suborbital timescales during the midPleistocene. Paleocenography 18 (1008), 13.

Krom, M.D., Kress, N., Brenner, S., Gordon, L.I., 1991. Phosphorus limitation of primary productivity in the Eastern Mediterranean sea. Limnology and Oceanography 36, 424-432.

Krom, M.D., Emeis, K.-C., Van Cappellen, P., 2010. Why is the Eastern Mediterranean phosphorus limited? Progress in Oceanography 85, 236-244.

Kucera, M., Kennett, J.P., 2002. Causes and consequences of a middle Pleistocene origin of the modern planktonic foraminifer Neogloboquadrina pachyderma sinistral. Geology 30, 539-542.

Larrasoaña, J.C., Roberts, A.P., Stoner, J.S., Richter, C., Wehausen, R., 2003. A new proxy for bottom-water ventilation in the eastern Mediterranean based on diagenetically controlled magnetic properties of sapropel-bearing sediments. Palaeogeography, Palaeoclimatology, Palaeoecology 190, 221-242.

Laskar, J., Robutel, P., Joutel, F., Gastineau, M., Correia, A.C.M., Levrard, B., 2004. A longterm numerical solution for the insolation quantities of the Earth. Astronomy and Astrophysics 428, 261-285.

Linares, D., Gonzales-Donoso, J.M., Serrano, F., 1999. Paleoceanographic conditions during the Quaternary at Sites 976 (Alboran Sea) and 975 (Menorca Rise) inferred from the planktonic foraminifera assemblages: Basis for a biostratigraphy. In: Zahn, R., Comas, M.C., Klaus, A. (Eds.), Proceedings of the Ocean Drilling Program, Scientific Results, 161, pp. 441-455.

Lisiecki, L.E., Raymo, M.E., 2005. Pliocene-Pleistocene stack of 57 globally distributed benthic $\delta^{18} \mathrm{O}$ records. Paleoceanography 20. http://dx.doi.org/10.1029/2004PA001071.

Lomb, N.R., 1976. Least-square frequency analysis of unequally spaced data. Astrophysical Space Science 29, 447-462.

Lourens, L., 2004. Revised tuning of Ocean Drilling Program Site 964 and KC01B (Mediterranean) and implications for the $\delta^{18} \mathrm{O}$, tephra, calcareous nannofossil, and geomagnetic reversal chronologies of the past 1.1 Myr. Paleoceanography 19, 1-20.

Lourens, L.J.A., Antonarakou, F.J., Hilgen, F.J., Van Hoof, A.A.F., Vergnaud Grazzini, C. Zachariasse, W.J., 1996. Evaluation of the Plio-Pleistocene astronomical time scale. Paleoceanography 11, 391-431.

Maiorano, P., Marino, M., 2004. Calcareous nannofossil bioevents and environmenta control on temporal and spatial patterns at the early-middle Pleistocene. Marine Micropaleontology 53, 405-422.

Maiorano, P., Marino, M., Di Stefano, E., Ciaranfi, N., 2004. Calcareous nannofossil events in the lower-middle Pleistocene transition at the Montalbano Jonico section and ODP Site 964: calibration with isotope and sapropel stratigraphy. Rivista Italiana di Paleontologia e Stratigrafia 110, 547-556.

Manabe, S., Stouffer, R.J., 1997. Coupled Ocean-atmosphere model Response to Freshwater Input: Comparison with Younger Dryas Event. Paleoceanography 12, 321-336.

Marino, G., Rohling, E.J., Rijpstra, W.I.C., Sangiorgi, F., Schouten, S., Sinninghe Damsté J.S., 2007. Aegean Sea as driver of hydrographic and ecological changes in the eastern Mediterranean. Geology 35, 333-349.

Marino, M., Maiorano, P., Lirer, F., 2008. Changes in calcareous nannofossil assemblages during the Mid-Pleistocene Revolution. Marine Micropaleontology 69, 70-90.

Marino, M., Maiorano, P., Lirer, F., Pelosi, N., 2009. Response of calcareous nannofossil as semblages to paleoenvironmental changes through the mid-Pleistocene revolution at Site 1090 (Southern Ocean). Palaeogeography, Palaeoclimatology, Palaeoecology 280 153-174.

Marlow, J.R., Lange, C., Wefer, G., Rosell-Melé, A., 2000. Upwelling intensification as part of the Pliocene-Pleistocene climate transition. Science 290, 2288-2291.

Martínez-Garcia, A., Rosell-Melé, A., Jaccard, S.L., Geibert, W., Sigman, D.M., Haug, G.H., 2011 Southern Ocean dust-climate coupling during the past four million years. Nature 476 312-315.

Martrat, B., Grimalt, J.O., Lopez-Martinez, C., Cacho, I., Sierro, F.J., Flores, J.A., Zahn, R. Canals, M., Curtis, J.H., Hodell, D.A., 2004. Abrupt Temperature Changes in the Western Mediterranean over the Past 250,000 Years. Science 306, 1762-1765.

McClymont, E.L., Rosell-Melè, A., 2005. Links between the onset of modern Walker circulation and the mid-Pleistocene climate transition. Geology 33, 389-392.

Millot, C., 1999. Circulation in the western Mediterranean Sea. Journal of Marine Systems 20, 423-442.
Mix, A.C. Pisias, N.G., Rugh, W., Wilson, J., Morey, A., Hagelberg T.K. 1995. Benthic foraminifera stable isotope record from Site 849 (0-5 Ma): Local and global climate changes. In: Pisias, N.G., Mayer, L.A., Janecek, T.R., Palmer-Julson, A., van Andel, T.H. (Eds.), Proceedings of the Ocean Drilling Program: Scientific Results, 138, pp. 371-412.

Morel, A., André, J.-M., 1991. Pigment distribution and primary production in the western Mediterranean as derived and modeled from coastal zone color scanner observations. Journal of Geophysical Research 96, 12,685-12,698.

Negi, J.G., Tiwari, R.K., 1984. Periodicities of palaeomagnetic intensity and palaeoclimatic variations: a Walsh spectral approach. Earth and Planetary Science Letters 70, 3-24.

Ovchinnikov, I.M., 1984. The formation of Intermediate Water in the Mediterranean. Oceanology 24, 139-147.

Pérez-Folgado, M., Sierro, F.J., Flores, J.-A., Cacho, I., Grimalt, J.O., Zahn, R., 2003. Western Mediterranean planktonic foraminifera events and climatic variability during the last 70 kyr. Marine Micropaleontology 48, 49-70.

Pérez-Folgado, M., Sierro, F.J., Flores, J.-A., Grimalt, J.O., Zahn, R., 2004. Paleoclimatic variations in foraminifer assemblages from the Alboran Sea (Western Mediterranean) during the last $150 \mathrm{ka}$ in ODP Site 977. Marine Geology 212, 113-131.

Pinardi, N., Masetti, E., 2000. Variability of the large scale general circulation of the Mediterranean Sea from observations and modelling: a review. Palaeogeography, Palaeoclimatology, Palaeoecology 158, 153-174.

Pisias, N.G., Moore Jr., T.C., 1981. The evolution of the Pleistocene climate: a time series approach. Earth and Planetary Science Letters 52, 450-458.

POEM group, 1992. General circulation of the Eastern Mediterranean. Earth-Science Reviews 32, 285-309.

Pujol, C., Vergnaud-Grazzini, C., 1995. Distribution patterns of live planktonic foraminuifers as related to regional hydrography and productive system of the Mediterranean Sea. Marine Micropaleontology 25, 187-217.

Raffi, I., 2002. Revision of the early-middle Pleistocene calcareous nannofossil biochronology (1.75-0.85 Ma). Marine Micropaleontology 45, 25-55.

Raymo, M.E., Ruddimann, W.F., Shackleton, N.J., Oppo, D.W., 1990. Evolution of the Atlantic-Pacific $\delta^{13} \mathrm{C}$ gradients over the last 2.5 m.y. Earth and Planetary Science Letters 97, 353-368.

Rea, D.K., 1994. The paleoclimatic record provided by Eolian deposition in the deep sea: The geologic history of wind. Reviews of Geophysics 32, 159-195.

Rio, D., Raffi, I., Villa, G., 1990. Pliocene-Pleistocene calcareous nannofossil distribution patterns in the western Mediterranean. In: Kastens, K.A. (Ed.), Proceedings of the Ocean Drilling Program, Scientific Results, 107, pp. 513-533.

Robinson, A.R., Sellschopp, J., Warn-Varnas, A., Leslie, W.G., Lozano, C.J., Haley Jr., P.J., Anderson, L.A., Lermusiaux, P.F.J., 1999. The Atlantic Ionian Stream. Journal of Marine Systems 20, 129-156.

Rohling, E.J., 1994. Review and new aspects concerning the formation of Mediterranean sapropels. Marine Geology 122, 1-28.

Rohling, E.J., Gieskes, W.W.C., 1989. Late Quaternary changes in Mediterranean Intermediate Water density and formation rate. Paleoceanography 4, 531-545.

Rohling, E.J., Jorissen, F.J., Vergnaud-Grazzini, C., Zachariasse, W.J., 1993. Northern Levantine and Adriatic Quaternary planktic foraminifera: Reconstruction of paleoenvironmental gradients. Marine Micropaleontology 21, 191-218.

Rohling, E.J., Hayes, A., De Rijk, S., Kroon, D., Zachariasse, W.J., Eisma, D., 1998. Abrupt cold spells in the northwest Mediterranean. Paleoceanography 13, 316-322.

Rohling, E.J., Cane, T.R., Cooke, S., Sprovieri, M., Bouloubassi, I., Emeis, K.C., Schiebel, R., Kroon, D., Jorissen, F.J., Lorre, A., Kemp, A.E.S., 2002a. African monsoon variability during the previous interglacial maximum. Earth and Planetary Science Letters 202, 61-75.

Rohling, E.J., Mayewsky, P.A., Abu-Zied, R.H., Casford, J.S.L., Hayes, A., 2002b. Holocene atmosphere-ocean interaction: records from Greenland and the Aegean Sea. Climate Dynamics 18, 587-593.

Rohling, E.J., Sprovieri, M., Cane, T., Casford, J.S.L., Cooke, S., Bouloubassi, I., Emeis, K.C., Schiebel, R., Rogerson, M., Hayes, A., Jorissen, F.J., Kroon, D., 2004. Reconstructing past planktic foraminiferal habitats using stable isotope data: a case history for Mediterranean sapropel S5. Marine Micropaleontology 50, 89-123.

Rossignol-Strick, M., 1983. African monsoons, an immediate response to orbital insolation. Nature 30, 446-449.

Rossignol-Strick, M., 1985. Mediterranean Quaternary sapropels, an immediate response of the African Monsoon to variation of insolation. Palaeogeography, Palaeoclimatology, Palaeoecology 49, 237-263.

Ruddimann, W., Raymo, M., Martinson, D., Clement, B., Backman, J., 1989. Pleistocene evolution: Northern Hemisphere ice sheets and North Atlantic Ocean. Paleoceanography $4,353-412$

Sarmiento, J., Herbert, T., Toggweiler, J.R., 1988. Mediterranean nutrient balance and episodes of anoxia. Global Biogeochemical Cycles 2, 427-444.

Sbaffi, L., Wezel, F.C., Kallel, N., Paterne, M., Cacho, I., Ziveri, P., Shackleton, N., 2001. Response of the pelagic environment to palaeoclimatic changes in the central Mediterranean Sea during the Late Quaternary. Marine Geology 178, 39-62.

Scargle, J.D., 1982. Studies in astronomical time series analysis, II Statistical aspects of spectral analysis of unevenly spaced data. Astrophysics Journal 263, 835-853.

Schefus, E., Sinnnghe Damstè, J.S.S., Jansen, J.H.F., 2004. Forcing of tropical Atlantic sea surface temperatures during the mid-Pleistocene transition. Paleoceanography 20. http://dx.doi.org/10.1029/2005PA001134.

Schulz, M., Mudelsee, M., 2002. REDFIT: estimating red-noise spectra directly from unevenly spaced paleoclimatic time series. Computer Geoscience 28, 421-426.

Siani, G., Paterne, M., Colin, C., 2010. Late glacial to Holocene planktic foraminifera bioevents and climatic record in the South Adriatic Sea. Journal of Quaternary Science 25, 808-821.

Sierro, F.J., Hodell, D.A., Curtis, J.H., Flores, J.-A., Reguera, I., Colmenero-Hidalgo, E., Bárcena, M.A., Grimalt, J.O., Cacho, I., Frigola, J., Canals, M., 2005. Impact of iceberg melting on Mediterranean thermohaline circulation during Heinrich Events. Paleoceanography 20. http://dx.doi.org/10.1029/2004PA001051. 
Sprovieri, R., Di Stefano, E., Howell, M., Sakamoto, T., Di Stefano, A., Marino, M., 1998. Integrated calcareous plankton biostratigraphy and cyclostratigraphy at Site 964 . In: Emeis, K.-C., Robertson, A.H.F., Richter, C., Camerlenghi, A. (Eds.), Proceedings of the Ocean Drilling Program, Scientific Results, 160, pp. 155-165.

Sprovieri, R., Di Stefano, E., Incarbona, A., Gargano, M.E., 2003. A high-resolution record of the last deglaciation in the Sicily Channel based on foraminifera and calcareous nannofossil quantitative distribution. Palaeogeography, Palaeoclimatology, Palaeoecology 202, 119-142.

Sprovieri, R., Di Stefano, E., Incarbona, A., Oppo, D.W., 2006. Suborbital climate variability during Marine Isotopic Stage 5 in the central Mediterranean Basin: evidence from calcareous plankton. Quaternary Science Reviews 25, 2332-2342.

Sprovieri, M., Di Stefano, E., Incarbona, A., Salvagio Manta, D., Pelosi, N., Ribera d'Alacalà, M., Sprovieri, R., 2012. Centennial- to millennial-scale climate oscillations in the Central-Eastern Mediterranean Sea between 20,000 and 70,000 years ago: evidence from a high-resolution geochemical and micropaleontological record. Quaternary Science Reviews 46, 126-135.

Sun, Y., Clemens, S.C., An, Z., Yu, Z., 2006. Astronomical timescale and paleoclimatic implication of stacked 3.6-Myr monsoon records from the Chinese Loess Plateau. Quaternary Science Reviews 25, 33-48.

Thunell, R.C., 1978. Distribution of recent planktonic foraminifera in surface sediments of the Mediterranean Sea. Marine Micropaleontology 3, 147-173.
Tiedemann, Sarnthein, M., Shackleton, N.J., 1994. Astronomic timescale for the Pliocene Atlantic $\delta^{18} \mathrm{O}$ and dust flux record of Ocean Drilling Program Site 659 Paleoceanography $14,571-588$.

Trauth, M.H., Larrasoaña, J.C., Mudelsee, M., 2009. Trends, rhytms and events in PlioPleistocene African climate. Quaternary Science Reviews 28, 399-411.

Triantaphyllou, M.V., Ziveri, P., Gogou, A., Marino, G., Lykousis, V., Boulobassi, Emeis, K.-C., Kouli, K., Dimiza, M., Rosell-Melé, A., Papanikolaou, M., Katsouras, G., Nunez, N., 2009 Late Glacial-Holocene climate variability at the south-eastern margin of the Aegean Sea. Marine Geology 266, 182-197.

Tziperman, E., Raymo, M.E., Huybers, P., Wunsch, C., 2006. Consequences of pacing the Pleistocene $100 \mathrm{kyr}$ ice ages by nonlinear phase locking to Milankovitch forcing. Paleoceanography 21. http://dx.doi.org/10.1029/2005PA001241.

Vellinga, M., Wood, R.A., 2002. Global Climatic Impacts of a Collapse of the Atlantic Thermohaline Circulation. Climate Change 54, 251-267.

Venz, K.A., Hodell, D.A., 2002. New evidence for changes in Plio-Pleistocene deep water circulation from Southern Ocean ODP Leg 177 Site 1090. Palaeogeography, Palaeoclimatology, Palaeoecology 182, 197-220.

Žarić, S., Donner, B., Fischer, G., Mulitza, S., Wefer, G., 2005. Sensitivity of planktic foraminifera to sea surface temperature and export production as derived from sediment trap data. Marine Micropaleontology 55, 75-105. 